\title{
PENGARUH PERBEDAAN KEMAMPUAN AWAL TERHADAP PRESTASI BELAJAR PADA MATA KULIAH KIMIA DASAR
}

\author{
Ika Farida Yuliana \\ Universitas Billfath
}

INFO ARTIKEL

Diterima: 19-12-2020 Abstrak: Tujuan penelitian ini adalah untuk mengetahui pengaruh perbedaan Disetujui: 2-2-2021

\begin{tabular}{lr}
\hline Kata Kunci: & \\
pemahaman & konsep; \\
kemampuan & awal; \\
prestasi & belajar; \\
kimia dasar I &
\end{tabular}
kemampuan awal mahasiswa terhadap prestasi belajar pada mata kuliah Kimia Dasar I. Rancangan penelitian yang digunakan adalah kualitatif deskriptif. Subjek penelitian adalah mahasiswa program studi Pendidikan Kimia Angkatan 2017 yang menempuh mata kuliah Kimia Dasar 1. Penelitian ini dilakukan melalui tiga (3) tahap yaitu identifikasi karakteristik, identifikasi kemampuan awal, dan analisis pemahaman. Teknik pengumpulan data menggunakan wawancara dan tes. Hasil penelitian menunjukkan bahwa tingkat kemampuan awal mahasiswa mempengaruhi prestasi belajar dalam mata kuliah Kimia Dasar I.

\begin{abstract}
The study aim to determine the effect of differences in students' initial abilities on learning achievement in Basic Chemistry subjects I. The research design used was descriptive qualitative. The research subjects were students of the Chemical Education Study Program Class of 2017 who took the Basic Chemistry course 1. This research was conducted in three (3) stages, namely identification of characteristics, identification of initial abilities, and analysis of understanding. Data collection techniques using interviews and tests. The results showed that the level of students' initial ability influenced learning achievement in the Basic Chemistry course I.
\end{abstract}

Alamat Korespondensi:

Nama : Ika Farida Yuliana, M.Pd.

Instansil : Pendidikan Kimia, Universitas Billfath

Alamat instansi : Kompleks PP Al Fattah, Desa Siman, Kecamatan Sekaran, Kabupaten

Lamongan, Jatim

Surel: ikafarida.kimia@gmail.com

Universitas Billfath merupakan salah satu perguruan tinggi baru yang ada di wilayah Kabupaten Lamongan. Universitas Billfath beroperasional berdasarkan SK Kemenristekdikti RI Nomor 426/KPT/I/2016. Universitas Billfath memiliki 10 program studi yang terbagi dalam 4 (empat) fakultas, salah satunya adalah Program Studi Pendidikan Kimia yang berada dalam naungan FKIP. Sebagai program studi baru, tentunya Pendidikan Kimia masih harus berjuang untuk memperoleh mahasiswa baru sebanyak mungkin demi keberlanjutan lembaga.

Pada tahun akademik 2017/2018, Program Studi Pendidikan Kimia memperoleh mahasiswa baru sebanyak 14 orang sebagai angkatan pertama. Seluruh mahasiswa Pendidikan Kimia angkatan pertama memiliki latar belakang pendidikan yang berbeda, yakni SMA/Sederajat dari berbagai jurusan. Sebanyak 53,85\% mahasiswa merupakan lulusan MA dengan jurusan IPA, 23,08\% mahasiswa merupakan lulusan SMA dengan jurusan IPA, 7,69\% mahasiswa merupakan lulusan SMA dengan jurusan IPS, 7,69\% mahasiswa merupakan lulusan SMK dengan rusan Teknik Komputer dan Jaringan (TKJ), dan 7,69\% mahasiswa merupakan lulusan SMK dengan jurusan Perbankan. Perbedaan latar belakang keilmuan dari mahasiswa baru tersebut, tentunya mereka juga memiliki kemampuan awal belajar yang berbeda pula, khususnya dalam mempelajari ilmu kimia.

Kemampuan awal merupakan salah satu modal awal bagi mahasiswa dalam memproses pengetahuan baru yang dipelajari. Kemampuan awal tersebut juga menjadi salah satu faktor yang mempengaruhi hasil belajar mahasiswa. Kemampuan awal juga menggambarkan bagaimana keterampilan awal yang dimiliki oleh mahasiswa, sehingga kemampuan awal merupakan salah satu prasyarat yang harus dikuasai mahasiswa pada awal pembelajaran 
(Herawati, dkk, 2013:38). Pada umumnya, mahasiswa yang memiliki kemampuan awal lebih baik akan memiliki kecenderungan lebih mudah untuk memahami materi dibandingkan mahasiswa yang berkemampuan awal lebih rendah (Danial,dkk, 2017:21). Maka dari itu, kemampuan awal merupakan salah satu faktor internal (psikologis) 2 yang dapat mpengaruhi hasil belajar (Ahmad, dkk, 2017:86) dan sebagai salah satu penentu tercapainya tujuan pembelajaran.

Berdasarkan uraian tersebut, maka setiap dosen wajib mengetahui bagaimana kemampuan awal mahasiswanya agar dosen dapat menyesuaikan model/strategi mana yang digunakan dalam mencapai tujuan pembelajaran.

\section{METODE}

Rancangan penelitian yang digunakan dalam penelitian ini adalah kualitatif deskriptif, yaitu rancangan penelitian yang berusaha untuk mendeskripsikan suatu gejala peristiwa atau kejadian secara sistematis dan akurat serta mendalam. Penelitian telah dilaksanakan selama Semester Ganjil Tahun Akademik 2017/2019. Subjek penelitian adalah mahasiswa Program Studi Pendidikan Kimia yang menempuh mata kuliah Kimia Dasar I.

Ada 3 (tiga) tahapan dalam pengumpulan data, yaitu identifikasi karakteristik, identifikasi kemampuan awal, dan analisis pemahaman mahasiswa. Identifikasi karakteristik mahasiswa bertujuan untuk menggali berbagai informasi terkait karakteristik non akademik setiap individu. Pada tahap identifikasi kemampuan awal dilakukan untuk mengetahui seberapa jauh mahasiswa mengenal dan memahami ilmu kimia di sekolah asal. Analisis pemahamn mahasiswa dilakukan saaat Ujian Tengah Semester (UTS) dan Ujian Akhir Semester (UAS). Hal ini dilakukan lebih menganalisis tingkat pemahaman mahasiswa terhadap seluruh materi yang disampaikan dalam perkuliahan Kimia Dasar I.

Pengumpulan data dalam penelitian ini dilakukan dengan menggunakan instrument wawancara dan tes yang diberikan kepada mahasiswa, Data yang diperoleh dari semua instrumen kemudian dianalisis untuk mengetahui pengaruh perbedaan keammpuan awal terhadap prestasi belajar mahasiswa angkatan pertama di Universitas Billfath.

\section{HASIL}

Data kemampuan awal mahasiswa pada materi Kimia Dasar I pada penelitian ini dilihat dari hasil nilai pretest yang dilakukan terhadap mahasiswa sebelum memperoleh perkuliahan Kimia Dasar I. Data ini menunjukan kemampuan awal yang dimiliki mahasiswa dari hasil belajar selama sekolah pada sekolah menengah atas. Sehingga nilai pretest ini menunjukkan tingkat kemampuan awal yang dimiliki oleh masing-masing mahasiswa. Data kemampuan awal ini ditunjukkan dalam tabel berikut.

Tabel 1. Data Kemampuan Awal Mahasiswa

\begin{tabular}{cccc}
\hline Mahasiswa & Nilai & Tingkat Kemampuan Awal & Rata-rata Kelas \\
\hline 1 & 55 & Tinggi & \\
2 & 35 & Rendah & \\
3 & 75 & Tinggi & \\
4 & 20 & Rendah & \\
5 & 25 & Rendah & \\
6 & 65 & Tinggi & \\
7 & 55 & Tinggi & \\
8 & 10 & Rendah & \\
9 & 15 & Rendah & \\
10 & 55 & Tinggi & \\
11 & 65 & Tinggi & \\
12 & 30 & Rendah & \\
13 & 65 & Tinggi & \\
14 & 40 & Rendah & \\
\hline
\end{tabular}


Data kemampuan di atas dapat dikelompokkan menjadi 2 (dua) kelompok besar kemampuan awal, yaitu kemampuan awal tinggi dan kemampuan awal rendah. Pengelompokkan ini didasarkan pada nilai rata-rata kelas. Mahasiswa yang memiliki nilai di atas rata-rata, dikelompokkan menjadi mahasiswa dengan kemampuan awal tinggi, sedangkan mahasiswa yang memiliki nilai di bawah nilai rata-rata dikategorikan dalam kelompok mahasiswa dengan kemampuan awal rendah.

Pengelompokkan kelompok kemampuan awal ini juga ditunjang dari hasil wawancara yang dilakukan terhadap masing-masing mahasiswa. Dari hasil wawancara awal dan biodata mahasiswa diketahui bahwa seluruh mahasiswa Pendidikan Kimia angkatan 2017 memiliki latar belakang pendidikan yang berbeda, yakni SMA/Sederajat dari berbagai jurusan. Sebanyak 53,85\% mahasiswa merupakan lulusan MA dengan jurusan IPA, 23,08\% mahasiswa merupakan lulusan SMA dengan jurusan IPA, 7,69\% mahasiswa merupakan lulusan SMA dengan jurusan IPS, 7,69\% mahasiswa merupakan lulusan SMK dengan jurusan Teknik Komputer dan Jaringan (TKJ), dan 7,69\% mahasiswa merupakan lulusan SMK dengan jurusan Perbankan.

\section{Prestasi Belajar}

Prestasi belajar mahasiswa dalam penelitian ini ditunjukkan dengan nilai UTS dan UAS masing-masing mahasiswa. Hasil nilai UTS menunjukkan 42,85\% mahasiswa memperoleh nilai diatas rata-rata dan juga diatas nilai Kelulusan. Semua mahasiiswa yang memiliki nilai diatas rata-rata ini adalah mahasiswa dengan kemampuan awal tinggi. Sedangkan untuk hasil UAS, 50\% mahasiswa mendapatkan nilai diatas nilai kelulusan dan semuanya juga merupakan mahasiswa dengan kemampuan awal tinggi.

Hasil belajar ini diuji dengan soal tes berjumlah 10 butir soal essay. Prosentase jawaban benar untuk masing-masing butir soal adalah $80 \%$ (untuk butir soal 9), 60\% (untuk butir 1, 3, 4, dan 8), 50\% (untuk butir 5 dan 7), 40\% (untuk butir 2 dan 6), dan 30\% (untuk butir 10). Prosesntase kebenaran tertinggi ada pada soal butir 9 yang menguji mengenai kemampuan mahasiswa untuk menentukan golongan dan periode unsur dari konfigurasi elektronnya. Ini merupakan konsep dasar dalam konsep struktur atom. Hasil ini menunjukkan bahwa pemahaman mahasiswa terhadap materi struktur atom sudah cukup baik.

Berikut adalah contoh jawaban mahasiswa yang menunjukkan kesalahan konsep dalam memahami kaidah octet dan dan duplet.

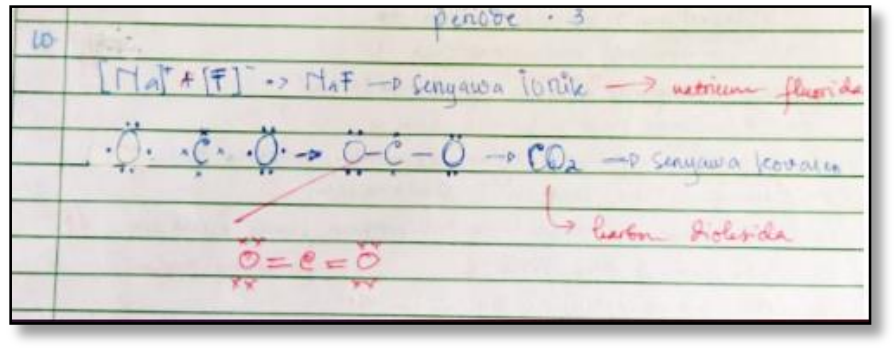

Gambar 1. Jawaban siswa

\section{PEMBAHASAN}

Berdasarkan data pada Tabel 1 dan data wawancara yang telah dilakukan, dapat diketahui bahwa mahasiswa angkatan pertama Universitas Billfath dapat dikelompokkan menjadi dua kelompok yaitu kelompok kemampuan awal tinggi dan rendah. Semua mahasiswa dengan kemampuan awal tinggi merupakan mahasiswa yang berasal dari SMA jurusan IPA sementara mahasiswa dengan kelompok kemampuan awal rendah berasal dari mahasiswa dengan berbagai jurusan saat di SMA. Data ini menunjukkan bahwa mahasiswa yang sudah memiliki kemampuan awal dalam hal IPA menunjukkan hasil yang lebih tinggi sehingga dikategorikan mahasiswa dengan kemampuan awal tinggi. Hal ini membuktikan bahwa kemampuan awal adalah kemampuan yang sudah dimiliki oleh mahasiswa sebelumnya, sehingga mahasiswa dengan latar belakang pendidikan IPA akan lebih siap dalam menjawab soal Kimia Dasar karena mereka sudah memiliki pengetahuan yang lebih mengenai materi dalam Kimia Dasar I 
dibandingkan dengan mahasiswa lain yang bukan berasal dari juruan IPA. Hal ini sesuai dengan pernyataan Irawati (2014) bahwa siswa dengan kemampuan awal lebih tinggi lebih siap dalam menerima konsep.

Prestasi belajar mahasiswa pada mata kuliah Kimia dasar 1 disajikan dalam prosentase kebenaran dalam menjawab tiap soal yang diberikan. Prosentase $60 \%$ didapatkan untuk butir soal 1, 3, 4, dan 8. Empat soal ini merupakan soal pemahaman konsep. Semua mahasiswa yang belum benar dalam menjawab adalah mahasiswa dengan kemampuan awal rendah. Hal ini dikarenakan memang mereka baru sekali mengenal konsep ini sehingga pemahamannya masih kurang. Soal semacam ini membutuhkan pemahaman menyeluruh dan berjenjang akan konsepkonsep dasar kimia. Tema materi untuk tiga soal adalah ruang lingkup ilmu kimia sedangkan satu soal ini adalah struktur atom. Hasil ini menunjukkan bahwa kemampuan awal sangat mempengaruhi kesiapan mahasiswa dalam mempelajari materi dalam Kimia Dasar. Sesuai dengan latar belakang mahasiswa, mahasiswa yang sebelumnya berasal dari jurusan IPS maupun SMK kejuruan kurang siap dalam pembelajaran sehingga membuituhkan usaha ekstra dalam pemahaman. Dan usaha ini harus ditunjang dengan motivasi yang tinggi pula untuk mendapatkan hasil yang optimal.

Untuk lima butir soal lainnya memiliki presentasi 50\%, 40\% dan 30\%. Hasil ini menunjukkan bahwa pemahaman mahasiswa akan materi dalam lima butir soal ini masih sangat rendah. Lima soal ini merupakan soal untuk materi teori kuantum dan struktur atom. Sebagian besar mahasiswa masih kesulitan dalam pemahaman konsep ini dikarenakan konsep ini merupakan konsep yang bersifat abstrak sehingga membutuhkan pemahaman menyeluruh untuk setiap poin dalam konsep. Contohnya untuk soal nomer 10 yang hanya memiliki prosentase kebenaran $30 \%$. Soal ini meminta mahasiswa untuk menggambarkan struktur Lewis dari senyawa ionic dan senyawa kovalen. Untuk menjawah soal ini mahasiswa harus memahami konsep senyawa ionic dan kovalen serta gambaran simbolik dari struktur Lewisnya. Beberapa mahasiswa tidak menjawab untuk soal nomer 10 ini dan Ketika dilakukan wawancara akhir mahasiswa menjawab kalau bingung atau tidak bisa mengerjakan. Sementara mahassiwa lain yang mencoba menjawab namun masih salah cenderung masih belum memahami kaidah octet dan duplet. Sehinggan pengaplikasiannya dalam menggambarkan struktur Lewis mahassiwa akan mengalami kesulitan.

Secara keseluruhan dapat terlihat bahwa pengaruh kemampuan awal dangat berkaitan erat dengan prestasi belajar. Kemampuan awal tinggi akan memberikan dasar pemahaman materi yang lebih baik dibandingan kemampuan awal rendah. Hal ini karena mahasiswa yang memiliki kemampuan awal tinggi memiliki bekal untuk lebih siap dalam menerima materi Kimia Dasar. Hal ini sesuai dengan pernyataan Ahmar (2016) dan Rosa (2016) yang mendeskripsikan bahwa kemampuan awal berpengaruh terhadap pemahaman konsep kimia.

\section{SIMPULAN DAN SARAN Simpulan}

Kemampuan awal mahasiswa berpengaruh kepada presasi belajar dalam mata kuliah Kimia Dasar I. Mahasiswa dengan kemampuan awal tinggi memiliki prestasi belajar yang lebih tinggi dibandingkan mahasiswa yang memiliki kemampuan awal rendah.

\section{Saran}

Perlu dilakukan penelitian lanjutan terkait motivasi belajar. Selain itu, perlu dilakukan penelitian lanjutan terkait model pembelajaran yang sesuai dengan keberagaman kemampuan awal mahasiswa, agar tujuan pembelajaran dapat tercapai

\section{DAFTAR RUJUKAN}

Ahmad, F., Gani, T., \& Tanre, M. 2017. Pengaruh Model Pembelajaran dan Kemampuan Awal terhadap Hasil Belajar Peserta Didik dalam Materi Kimia Kelas XI IPA SMAN 4 Makassar. Chemistry Education Review (CER), Vol.1, No.1, 2017, pp. 84-91. 
KARANGAN: Jurnal Kependidikan, Pembelajaran, dan Pengembangan, Vol 03, No 01, Bulan Februari, Tahun 2021, Hal 21-25

Ahmar, D. S. 2016. Hubungan Antara Kemampuan Awal dengan Kemampuan Berpikir Kreatif dalam Kimia Peserta Didik Kelas XI IPA SMA Negeri se-Kabupaten Takalar. Sainsmat: Jurnal Ilmiah Ilmu Pengetahuan Alam, Vol. 5, No. 2, 2016, pp. 157-166.

Danial, M., Gani, T., \& Husnaeni, H., 2017. Pengaruh Model Pembelajaran dan Kemampuan Awal terhadap Kemampuan Berpikir Kritis dan Pemahaman Konsep Peserta Didik. Journal of Educational Science and Technology (EST), Vol. 3, No.1, 2017, pp. 18-32.

Herawati, R. F., Mulyani, S., \& Redjeki, T. 2013. Pembelajaran Kimia Berbasis Multiple Representasi Ditinjau dari Kemampuan Awal terhadap Prestasi Belajar Laju Reaksi Siswa SMA NEGERI I Karanganyar Tahun Pelajaran 2011/2012. Jurnal Pendidikan Kimia (JPK), Vol. 2 No. 2, 2013, pp. 38-43.

Iktafiyah, L., Ibnu, S., \& Fajaroh, F. 2018. Pengaruh Pogil dan Verifikasi serta Kemampuan Awal terhadap Hasil Belajar Kognitif dan Keterampilan Proses Sains Siswa. EduChemia (Jurnal Kimia dan Pendidikan), Vol. 3, No. 1, 2018, pp. 14-28.23

Irawati, R. K. 2014. Pengaruh Model Problem Solving dan Problem Posing serta Kemampuan Awal terhadap Hasil Belajar Siswa. Jurnal Pendidikan Sains, Vol. 2, No. 4, 2014, pp. 184-192.

Rosa, Novrita M., \& Pujiati, A. 2016. Pengaruh Waktu Belajar dan Kemampuan Awal Terhadap Pemahaman Konsep Kimia. Disampaikan dalam Simposium Nasional Inovasi dan Pembelajaran Sains, FMIPA Institut Teknologi Bandung, 21-22 Juli 2016. 